\title{
STRATEGI KEBIJAKAN PENGEMBANGAN DESA PESISIR (Studi di Empat Belas Desa Pesisir di Kabupaten Blitar Provinsi Jawa Timur)
}

\author{
Muhammad Lukman Hakim \\ Program Studi Ilmu Pemerintahan FISIP Universitas Brawijaya Malang \\ ${ }^{*}$ Coressponding Author, email : em.lukman79@ub.ac.id
}

\begin{abstract}
Abstrak
Penelitian ini bertujuan mengidentifikasi tipologi Desa di Wilayah Pesisir Kabupaten Blitar untuk kemudian merumuskan kebijakan pengembangan kebijakan untuk Desa Pesisir. Selain menggunakan Teori ABCD, penelitian ini menggunakan hasil analisis Indeks Pembangunan Desa dan analisis SWOT. Tahap analisis dalam SWOT adalah untuk memanfaatkan semua data dan informasi dalam model kuantitatif perumusan strategi. Analisis SWOT dilakukan pemindaian pertama (scanning) yang intinya adalah pengumpulan dan identifikasi data sebagai pra-analisis. Model yang digunakan dalam analisis SWOT dalam analisis tipologi dan pengembangan desa pesisir di Kabupaten Blitar adalah IFAS - EFAS (ringkasan analisis faktor strategis internal - eksternal). Analisis faktor strategi internal dan eksternal adalah pengolahan faktor-faktor strategis di lingkungan internal dan eksternal dengan memberikan bobot dan peringkat untuk masing-masing faktor strategis. Faktor strategis adalah faktor dominan kekuatan, kelemahan, peluang dan ancaman yang memengaruhi kondisi dan situasi yang ada dan memberikan manfaat jika diambil tindakan positif. Analisis lingkungan internal (IFAS) digunakan untuk mengetahui berbagai kemungkinan kekuatan dan kelemahan. Masalah strategis yang akan dipantau harus ditentukan karena masalah ini dapat memengaruhi pembangunan di masa depan. Menganalisis lingkungan eksternal (EFAS) untuk mengetahui berbagai peluang dan ancaman. Melalui tahap analisis seperti di atas, penelitian ini dapat merumuskan strategi kebijakan yang tepat dalam mengembangkan desa-desa di wilayah pesisir selatan Kabupaten Blitar.
\end{abstract}

Kata kunci: Pesisir Desa, pemberdayaan, strategi kebijakan

\section{Abstract}

This study seeks to identify the typology of the Village in the Coastal District of Blitar to then formulate a policy development policy for the Coastal Village. In addition to using the ABCD Theory, this study uses the results of the analysis of the Village Build Index and the SWOT analysis. The analysis stage in SWOT is to utilize all data and information in quantitative models of strategy formulation. SWOT analysis is carried out first scanning (scanning) which in essence is a data collection and identification as a pre-analysis. The models used in the SWOT analysis in typology analysis and the development of coastal villages in Blitar Regency are IFAS - EFAS (internal - external strategic factor analysis summary). Internal and external strategy factor analysis is the processing of strategic factors in the internal and external environment by giving a weighting and rating to each strategic factor. Strategic factors are the dominant factors of strengths, weaknesses, opportunities and threats that influence the existing conditions and situations and provide benefits if positive actions are taken. Analyze the internal environment (IFAS) to find out various possible strengths and weaknesses. Strategic issues to be monitored must be determined because these problems might affect development in the future. Analyzing the external environment (EFAS) to find out various opportunities and threats. Through the analysis phase as above, this research is expected to formulate an appropriate policy strategy in developing rural villages in the southern coastal region of Blitar Regency.

Keywords: Coastal Village, empowerment, policy strategy 
Jurnal Administrasi Negara

ISSN : 2598-4039 (Online)

ISSN : 2302-2231 (Print)
Muhammad Lukman Hakim

Prodi Ilmu Pemerintahan FISIP

Universitas Brawijaya Malang

\section{PENDAHULUAN}

Desa sebagai sebuah kawasan yang otonom berdasarkan UU No 6 Tahun 2014 diberikan hak-hak istimewa, diantaranya adalah terkait pengelolaan keuangan dan alokasi dana desa, pemilihan kepala desa serta proses pembangunan. Otonomi desa merupakan kebijakan pemerintah daerah yang diberikan kepada pemerintah desa untuk lebih mengoptimalkan potensi yang dimiliki, sehingga dapat memaksimalkan pendapatan desa untuk pembangunan dan mensejahterakan masyarakat. Dalam rangka mendukung kelancaran penyelenggaraan Pemerintahan Desa secara berdayaguna dan berhasil guna sehingga Desa mampu melaksanakan kewenangan untuk mengatur dan mengurus kepentingan dan kesejahteraan masyarakatnya maka diperlukan strategi pengembangan, terutama di desa desa Pesisir di lokasi penelitian.

Desa pesisir memiliki karakteristik yang berbeda dengan desa di wilayah pedalaman. Perbedaan tersebut tidak semata pada aspek geografis-ekologis, tetapi juga pada karakteristik ekonomi dan sosialbudaya. Secara geografis, desa pesisir berada di perbatasan antara daratan dan lautan. Desa pesisir memiliki akses langsung pada ekosistem pantai (pasir atau berbatu), mangrove, estuaria, padang lamun, serta ekosistem terumbu karang. Kondisi geografis-ekologis desa pesisir mempengaruhi aktivitas- aktivitas ekonomi di dalamnya. Kegiatan ekonomi di desa pesisir dicirikan oleh aktivitas pemanfaatan sumberdaya pesisir. Aktivitas ekonomi mencakup perikanan, perdagangan, wisata bahari, dan transportasi.

Dalam konteks ini pesisir Kabupaten Blitar yang menjadi lokasi penelitian merupakan suatu kawasan dengan topografi berupa bagian pesisir dan pegunungan berbatu, sehingga struktur tanahnya kurang subur. Kawasan pesisir Kabupaten Blitar memilki ekosistem yang cukup komplek seperti adanya areal tambang, persawahan, pemukiman hingga hutan mangrove. Ekosistem alami yang terdapat di kawasan pesisir antara lain adalah terumbu karang, mangrove, padang lamun, pantai berpasir, estuaria, laguna, dan delta. Ekosistem buatan antara lain tambak, sawah pasang surut, kawasan pariwisata, kawasan industri, kawasan agroindustri, dan kawasan pemukiman.

Lokasi penelitian meliputi seluruh desa pesisir yang ada di kabupaten Blitar meliputi: Kecamatan Bakung: (1)Tumpakepuh, (2)Plandirejo, (3)Tumpakoyot, (4)Sidomulyo, (5)Bululawang, Kecamatan Wonotirto: (6)Gununggede, (7)Kaligrenjeng, (8)Ngadipuro, (9)Tambakrejo, Kecamatan Penggungrejo: (10)Serang, (11)Sumbersih, Kecamatan Wates: (12)Tugurejo, (13)Tulungrejo, Ringinrejo. Untuk lebih memahami lokasi penelitian secara spasial, berikut penulis sajikan pada gambar 1 berikut: 


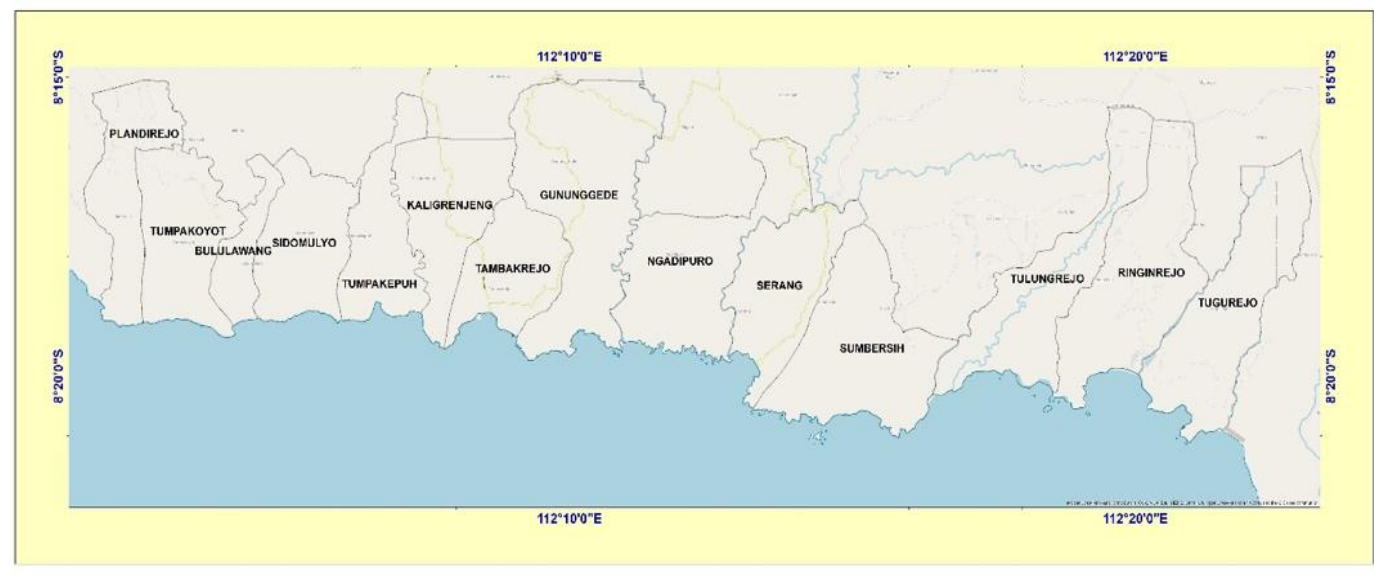

Gambar 1. Peta Lokasi Kegiatan

Sumber: Bappeda Kabupaten Blitar 2018

Dari empat belas desa yang peneliti kajia ada sejumlah isu kritis dalam pembangunan desa pesisir yang penulis temukan: terbagi ke dalam lima ranah: ekologi, sosial, ekonomi, agraria, dan geopolitik. Dalam upaya meneliti desa pesisir di lokasi penelitian. Peneliti melihatnnya dari Indeks Desa membangun yang dikeluarkan oleh Kementerian Desa dan metode SWOT untuk memetakan persoalan yang ada dilokasi untuk kemudian merumuskan startegi kebijakan pengembangannya.

Melalui langkah ini kajian ini setidaknya dapat menjawab dua permasalah yang penulis ajukan: pertama bagaimana tipologi desa diwilayah pesisir Kabupaten Blitar. Dan kedua, bagaimana strategi kebijakan dalam mengoptimalkan pengembangan Desa di wilayah Pesisir Kabupaten Blitar

Kedua pertanyaan ini penting diajukan untuk dapat merumuskan strategi kebijakan yang tepat dilokasi penelitian dimana wilayah pesisir memiliki karakterisktik yang sama sekali berbeda dengan wilayah pegunungan ataupun desa desa yang dekat dengan Kawasan perkotaan. Dengan demikian tujuan riset ini dapat tercapai yakni: mengidentifikasi tipologi Desa di Pesisir Kabupaten Blitar dan merumuskan strategi kebijakan optimalisasi pengembangan Desa di wilayah pesisir tersebut.

\section{METODE PENELITIAN}

Analisis dan penetuan tipologi desa-desa pesisir di Kabupaten Blitar didasarkan pada perhitungan yang telah disusun dalam kerangka Indeks Desa Membangun (IDM). Indeks Desa Membangun (IDM) merupakan acuan dalam perencanaan dan pengembangan desa yang telah resmi digunakan oleh Kementerian Desa. Indeks Desa Membangun mengklasifikasi Desa dalam lima (5) status, yaitu: (i) Desa Sangat Tertinggal; (ii) Desa Tertinggal; 
Jurnal Administrasi Negara

ISSN : 2598-4039 (Online)

ISSN : 2302-2231 (Print)
Muhammad Lukman Hakim

Prodi Ilmu Pemerintahan FISIP Universitas Brawijaya Malang (iii) Desa Berkembang; (iv) Desa Maju; dan (v) Desa Mandiri. Klasifikasi Desa tersebut untuk menunjukkan keragaman karakter setiap Desa dalam rentang skor 0,27 - 0,92 Indeks Desa Membangun. Klasifikasi dalam 5 status Desa tersebut juga untuk menajamkan penetapan status perkembangan Desa dan sekaligus rekomendasi intervensi kebijakan yang diperlukan. Status Desa Tertinggal, misalnya, dijelaskan dalam dua status Desa Tertinggal dan Desa Sangat Tertinggal di mana situasi dan kondisi setiap Desa yang ada di dalamnya membutuhkan pendekatan dan intervensi kebijakan yang berbeda. Menangani Desa Sangat Tertinggal akan berbeda tingkat afirmasi kebijakannya di banding dengan Desa Tertinggal.

Dengan nilai rata-rata nasional Indeks Desa Membangun 0,566 klasifikasi status Desa ditetapkan dengan ambang batas sebagai berikut:

1. Desa Sangat Tertinggal : $<0,491$

2. Desa Tertinggal : $>0,491$ dan $<0,599$

3. Desa Berkembang : > 0,599 dan < 0,707

4. Desa Maju : $>0,707$ dan $<0,815$

5. Desa Mandiri : $>0,815$

Indeks Variabel $=\frac{\Sigma \text { Indikator X }}{\text { Nilai Maksimum }(X)}$

1) Indeks dari setiap variabel menjadi Indeks Komposit yang disebut dengan Indeks Desa Membangun (IDM)

$$
\text { IDM = 1/3 (IS + IEK + IL) }
$$

IDM : Indeks Desa Membangun IS : Indeks Sosial
IEK : Indeks Ekonomi

IL : Indeks Lingkungan (Ekologi)

Penelitian ini juga menggunakan analisis SWOT. Kegiatan yang paling penting dalam proses analisis SWOT adalah memahami seluruh informasi dalam suatu kasus, menganalisis situasi untuk mengetahui isu apa yang sedang terjadi dan memutuskan tindakan apa yang harus segera dilakukan utuk memecahkan masalah. SWOT merupakan singkatan dari strengths (kekuatan-kekuatan), weaknesses (kelemahan-kelemahan), opportunities (peluang-peluang) dan threats (ancaman-ancaman). Pengertianpengertian kekuatan, kelemahan, peluang dan ancaman dalam analsis SWOT adalah sebagai berikut :

- Kekuatan (Strengths) Kekuatan adalah sumber daya, keterampilan atau keunggulan lain relatif terhadap pesaing dan kebutuhan dari suatu mekanisme pekerjaan/kegiatan.

- Kelemahan (Weaknesses) Kelemahan adalah keterbatasan/kekurangan dalam sumber daya alam, keterampilan dan kemampuan yang secara serius menghalangi kinerja efektif suatu pekerjaan/kegiatan.

Peluang (Opportunities) Peluang adalah situasi/kecenderungan utama yang menguntungkan dalam suatu lingkungan.

- Ancaman (Threats) Ancaman adalah situasi/kecenderungan utama yang tidak menguntungkan dalam lingkungan. 
Jurnal Administrasi Negara

ISSN : 2598-4039 (Online)

ISSN : 2302-2231 (Print)
Muhammad Lukman Hakim

Prodi Ilmu Pemerintahan FISIP

Universitas Brawijaya Malang

\section{PEMBAHASAN}

Penyusunan

strategi

pengembangan desa didasarkan pada kondisi saat ini/eksisting untuk melakukan perencanaan dan pengembangan desa di pesisir Kabupaten Blitar dengan memperhatikan kondisi kekuatan (strenght), kelemahan (weakness), peluang (opportunity), dan ancaman (threat) melalui analisis kondisi lingkungan internal (IFAS) dan lingkungan eksternal (EFAS) yang telah dilakukan sebelumnya.
Perumusan strategi dalam analisis tipologi dan pengembangan desa di pesisir Kabupaten Blitar dilakukan dengan penentuan kuadran strategi dalam analisis SWOT. Hasil analisis menunjukkan bahwa klasifikasi desadesa pesisir di Kabuapaten Blitar sebagai desa tertinggal dan berkembang. Berdasarkan klasifikasi tersebut maka strategi yang dapat dipilih adalah strategi agresif bertumbuh.

Tabel 1

Matrik IFAS untuk Desa Tertinggal

\begin{tabular}{|c|c|c|c|c|}
\hline No & Kekuatan & Bobot (a) & Rating (b) & Skor $\left(a^{*} b\right)$ \\
\hline 1 & Pelayanan Kesehatan & 0.11 & 3 & 0.32 \\
\hline 2 & Keberdayaan masyarakat untuk kesehatan & 0.07 & 3 & 0.22 \\
\hline 3 & Jaminan Kesehatan & 0.02 & 3 & 0.06 \\
\hline 4 & Akses Pendidikan Dasar dan Menengah & 0.07 & 3 & 0.20 \\
\hline 5 & Akses Pendidikan Non Formal & 0.02 & 3 & 0.06 \\
\hline 6 & Solidaritas Sosial & 0.02 & 5 & 0.12 \\
\hline 7 & Rasa Aman Masyarakat & 0.02 & 4 & 0.09 \\
\hline 8 & Kesejahteraan Sosial & 0.02 & 4 & 0.09 \\
\hline 9 & Akses ke Air Bersih dan Air Minum Layak & 0.09 & 4 & 0.37 \\
\hline 10 & Akses Sanitasi & 0.09 & 4 & 0.36 \\
\hline 11 & Akses Listrik & 0.09 & 4 & 0.36 \\
\hline 12 & Akses Informasi dan Komunikasi & 0.09 & 4 & 0.36 \\
\hline 13 & Keragaman Produksi Masyarakat & 0.02 & 3 & 0.05 \\
\hline 14 & Kualitas Lingkungan & 0.09 & 4 & 0.36 \\
\hline 15 & Keterbukaan Wilayah & 0.10 & 3 & 0.29 \\
\hline \multirow[t]{2}{*}{16} & Potensi Wisata & 0.09 & 4 & 0.35 \\
\hline & Jumlah & & & 3.63 \\
\hline No & Kelemahan & Bobot (a) & Rating (b) & Skor $\left(a^{*} b\right)$ \\
\hline 1 & Pelayanan Kesehatan & 0.19 & 4 & 0.78 \\
\hline 2 & Akses Pendidikan Dasar dan Menengah & 0.04 & 3 & 0.12 \\
\hline 3 & Akses Pengetahuan & 0.04 & 3 & 0.12 \\
\hline 4 & Solidaritas Sosial & 0.04 & 2 & 0.09 \\
\hline 5 & Rasa Aman Masyarakat & 0.04 & 2 & 0.08 \\
\hline 6 & Akses Sanitasi & 0.06 & 2 & 0.12 \\
\hline 7 & Pusat Pelayanan Perdagangan & 0.22 & 4 & 0.87 \\
\hline
\end{tabular}




\begin{tabular}{lllll}
\hline $\mathbf{8}$ & Akses Distribusi Logistik & 0.07 & 2 & 0.13 \\
\hline $\mathbf{9}$ & Akses ke Lembaga Keuangan dan Perkreditan & 0.04 & 2 & 0.08 \\
\hline $\mathbf{1 0}$ & Lembaga Ekonomi & 0.10 & 2 & 0.20 \\
\hline $\mathbf{1 1}$ & Keterbukaan Wilayah & 0.15 & 2 & 0.30 \\
\hline$\quad$ Jumlah & & & $\mathbf{2 . 8 8}$ \\
\hline & $\mathbf{X}=$ Kekuatan - Kelemahan & & $\mathbf{0 . 7 5}$ \\
\hline
\end{tabular}

Sumber: Data Lapangan Diolah Penulis, 2020

Tabel 2

Matrik EFAS untuk Desa Tertinggal

\begin{tabular}{lllll}
\hline $\mathbf{N o}$ & Peluang & Bobot (a) & Rating (b) & Skor $\left(\mathbf{a}^{*} \mathbf{b}\right)$ \\
\hline $\mathbf{1}$ & Kondisi Topografi/Morfologi & 0.13 & 4 & 0.50 \\
\hline $\mathbf{2}$ & Karakteristik Tanah & 0.13 & 4 & 0.50 \\
\hline $\mathbf{4}$ & Program Pemerintah & 0.38 & 4 & 1.50 \\
\hline $\mathbf{4}$ & Investasi & 0.38 & 4 & 1.50 \\
\hline $\mathbf{N o}$ & Aumlah & & & 4.00 \\
\hline $\mathbf{1}$ & Potensi/Rawan Bencana Alam & Bobot (a) & Rating (b) & Skor (a*b) \\
\hline $\mathbf{2}$ & Kondisi Topografi/Morfologi & 0.18 & 4 & 0.71 \\
\hline $\mathbf{3}$ & Keterbukaan Wilayah & 0.18 & 2 & 0.36 \\
\hline $\mathbf{4}$ & Pengelolaan Potensi Wilayah & 0.35 & 3 & 1.05 \\
\hline $\mathbf{5}$ & Urbanisasi & 0.22 & 3 & 0.67 \\
\hline & Jumlah & 0.07 & 2 & 0.15 \\
\hline & Y= Peluang - Ancaman & & & $\mathbf{2 . 9 3}$ \\
\hline
\end{tabular}

Sumber: Data Lapangan Diolah Penulis, 2020

Tabel 3

Kuadran SWOT untuk Desa Tertinggal

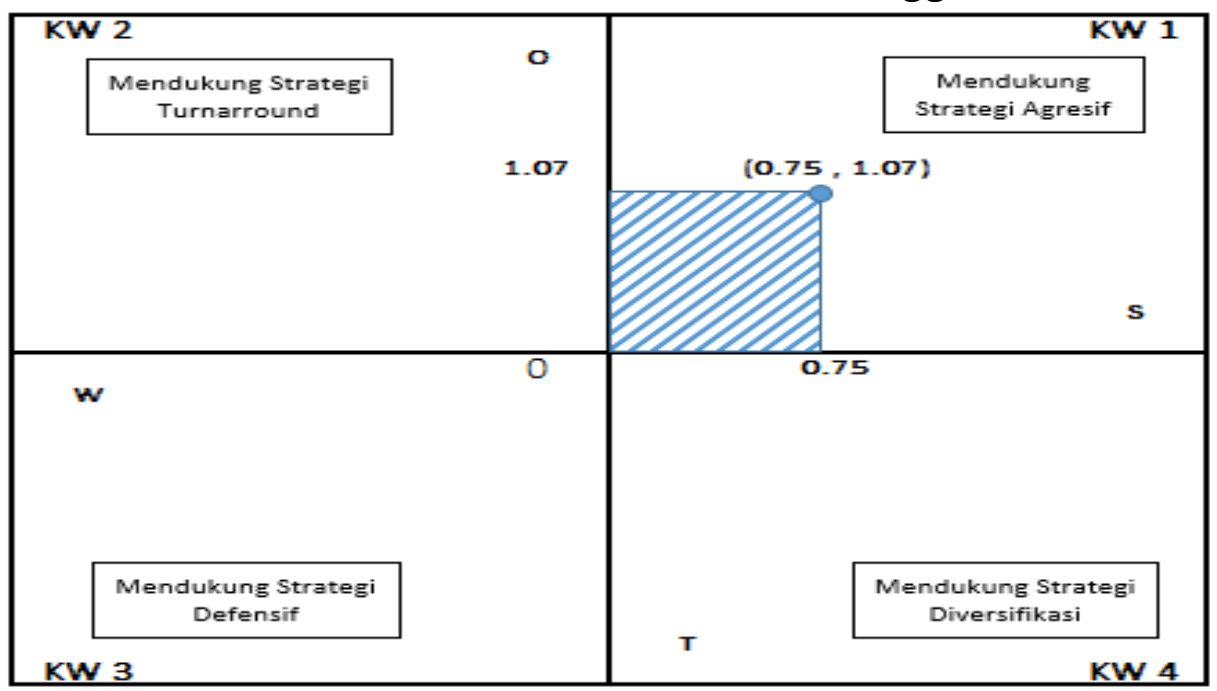

Sumber: Data Lapangan Diolah Penulis, 2020 
Tabel 4

Matrik IFAS untuk Desa Berkembang

\begin{tabular}{|c|c|c|c|c|}
\hline No & Kekuatan & Bobot (a) & Rating (b) & Skor $\left(a^{*} b\right)$ \\
\hline 1 & Pelayanan Kesehatan & 0.09 & 3 & 0.27 \\
\hline 2 & Keberdayaan Masyarakat utk Kesehatan & 0.06 & 3 & 0.18 \\
\hline 3 & Jaminan Kesehatan & 0.02 & 3 & 0.06 \\
\hline 4 & Akses Pendidikan Dasar dan Menengah & 0.06 & 3 & 0.18 \\
\hline 5 & Solidaritas Sosial & 0.02 & 3 & 0.06 \\
\hline 6 & Rasa Aman Penduduk & 0.02 & 4 & 0.09 \\
\hline 7 & Kesejahteraan Sosial & 0.02 & 4 & 0.09 \\
\hline 8 & Akses ke Air Bersih dan Air Minum Layak & 0.02 & 4 & 0.09 \\
\hline 9 & Akses ke Sanitasi & 0.08 & 4 & 0.32 \\
\hline 10 & Akses ke Listrik & 0.08 & 4 & 0.32 \\
\hline 11 & Akses Informasi dan Komunikasi & 0.08 & 4 & 0.32 \\
\hline 12 & Keragaman Produksi Masyarakat & 0.06 & 3 & 0.18 \\
\hline 13 & Tersedia Pusat Pelayanan Perdagangan & 0.10 & 5 & 0.50 \\
\hline 14 & Lembaga Ekonomi & 0.09 & 5 & 0.45 \\
\hline 15 & Keterbukaan Wilayah & 0.10 & 4 & 0.39 \\
\hline \multirow[t]{2}{*}{16} & Potensi Wisata & 0.11 & 5 & 0.55 \\
\hline & Jumlah & & & 4.03 \\
\hline No & Kelemahan & Bobot (a) & Rating (b) & Skor $\left(a^{*} b\right)$ \\
\hline 1 & Pelayanan Kesehatan & 0.20 & 4 & 0.80 \\
\hline 2 & Akses Pendidikan Dasar dan Menengah & 0.09 & 2 & 0.18 \\
\hline 3 & Akses Pendidikan Non Formal & 0.06 & 3 & 0.18 \\
\hline 4 & Akses Pengetahuan & 0.08 & 4 & 0.32 \\
\hline 5 & Solidaritas Sosial & 0.05 & 3 & 0.15 \\
\hline 6 & Akses ke Sanitasi & 0.07 & 3 & 0.21 \\
\hline 7 & Rasa Aman Penduduk & 0.09 & 2 & 0.18 \\
\hline 8 & Akses Distribusi/Logistik & 0.06 & 3 & 0.18 \\
\hline 9 & Akses ke Lembaga Keuangan dan Perkreditan & 0.05 & 3 & 0.15 \\
\hline 10 & Keterbukaan Wilayah & 0.10 & 2 & 0.20 \\
\hline \multirow[t]{3}{*}{11} & Kualitas Lingkungan & 0.15 & 3 & 0.45 \\
\hline & Jumlah & & & 3.00 \\
\hline & X= Kekuatan - Kelemahan & & & 1.03 \\
\hline
\end{tabular}

Sumber: Data Lapangan Diolah Penulis, 2020

Tabel 5

Matrik EFAS untuk Desa Berkembang

\begin{tabular}{lllll}
\hline No & Peluang & Bobot (a) & Rating (b) & Skor (a*b) \\
\hline $\mathbf{1}$ & Karakteristik Tanah & 0.13 & 4 & 0.50 \\
\hline $\mathbf{2}$ & Kondisi Topografi/Morfologi & 0.13 & 3 & 0.38 \\
\hline $\mathbf{3}$ & Program pemerintah & 0.38 & 5 & 1.88 \\
\hline $\mathbf{4}$ & Investasi & 0.38 & 5 & 1.88 \\
\hline$\quad$ Jumlah & & & 4.63 \\
\hline No & Ancaman & Bobot (a) & Rating (b) & Skor (a*b) \\
\hline
\end{tabular}


Jurnal Administrasi Negara

ISSN : 2598-4039 (Online)

ISSN : 2302-2231 (Print)
Muhammad Lukman Hakim

Prodi Ilmu Pemerintahan FISIP

Universitas Brawijaya Malang

\begin{tabular}{lllll}
\hline $\mathbf{1}$ & Potensi/Rawan Bencana Alam & 0.18 & 4 & 0.71 \\
\hline $\mathbf{2}$ & Kondisi Topografi/Morfologi & 0.18 & 4 & 0.71 \\
\hline $\mathbf{3}$ & Keterbukaan Wilayah & 0.35 & 3 & 1.05 \\
\hline $\mathbf{4}$ & Pengelolaan Potensi Wilayah & 0.22 & 3 & 0.67 \\
\hline $\mathbf{5}$ & Urbanisasi & 0.07 & 2 & 0.15 \\
\hline$\quad$ Jumlah & & & $\mathbf{3 . 2 9}$ \\
\hline$\quad$ Y = Peluang - Ancaman & & & $\mathbf{1 . 3 4}$ \\
\hline
\end{tabular}

Sumber: Data Lapangan Diolah Penulis, 2020

Tabel 6

Kuadran SWOT untuk Desa Berkembang

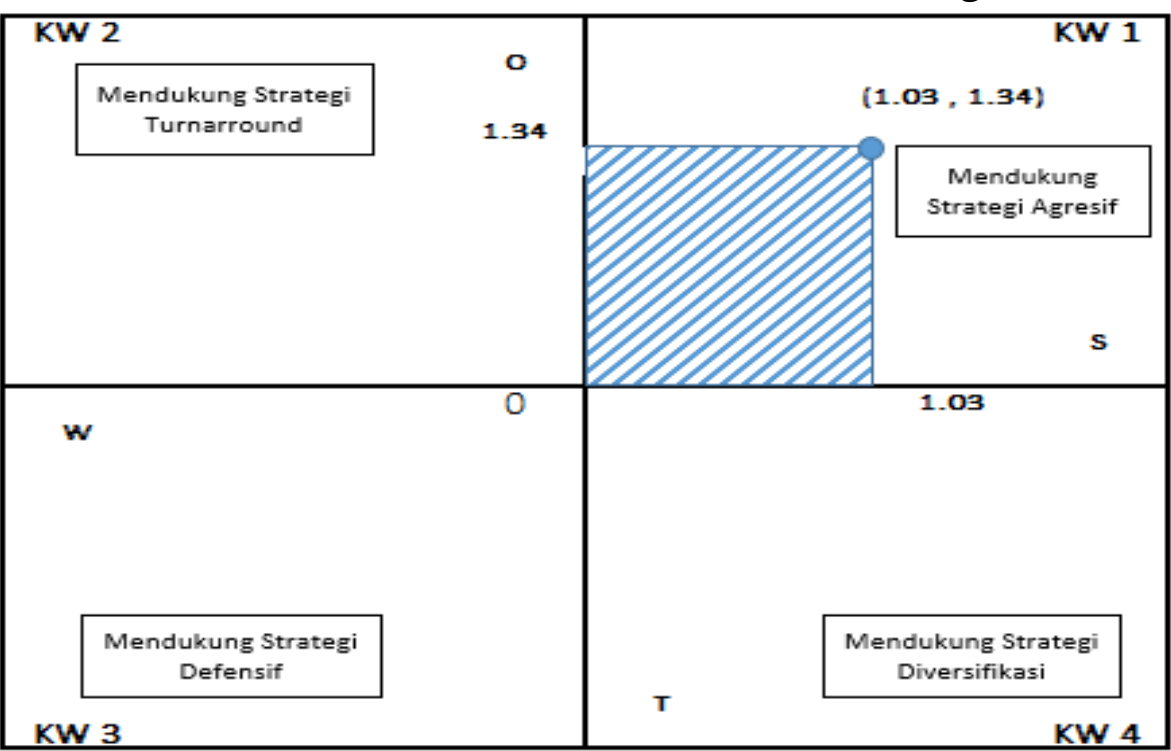

Sumber: Data Lapangan Diolah Penulis, 2020

Strategi agresif bertumbuh sebagaimana hasil dari analisis lingkungan internal dan eksternal. Selanjutnya disusun arah kebijakan yang mendukung strategi bertumbuh. Strategi dan arah kebijakan disusun sebagai pendekatan dalam memecahkan permasalahan yang mendesak untuk segera dilaksanakan dalam kurun waktu sepuluh tahun 2018-2028. Hal ini didasarkan pada RTRW Kabupaten Blitar yang disusun untuk tahun 20112031.

\section{RUMUSAN STRATEGI} PENGEMBANGAN

Rumusan strategi pengembangan desa di kawasan pesisir Kabupaten Blitar didasarkan pada analisis SWOT melalui IFAS dan EFAS. Rumusan dijabarkan dalam bentuk-bentuk program yang akan dilaksanakan oleh masing-masing desa di kawasan pesisir Kabupaten Blitar. Rumusan strategi pengembangan desa kawasan pesisir dapat diperinci sebagai berikut: 
Tabel 7

Rumusan Strategi Pembangunan Desa Pesisir

\begin{tabular}{|c|c|c|c|}
\hline $\begin{array}{l}\text { Rumusan } \\
\text { Kebijakan }\end{array}$ & Bentuk Kegiatan & Tujuan & $\begin{array}{l}\text { Nama } \\
\text { Desa }\end{array}$ \\
\hline \multirow[t]{4}{*}{$\begin{array}{l}\text { Pembangunan, } \\
\text { pengembangan dan } \\
\text { pemeliharaan } \\
\text { infrasruktur/sarana } \\
\text { prasarana fisik } \\
\text { untuk } \\
\text { penghidupan dan } \\
\text { pemukiman }\end{array}$} & $\begin{array}{l}\text { Pembangunan tembok } \\
\text { laut kawasan wisata laut }\end{array}$ & $\begin{array}{l}\text { 1. } \begin{array}{l}\text { Memperkuat } \\
\text { tebing/bibir pantai } \\
\text { lokasi wisata pantai; } \\
\text { 2. Mengurangi ancaman } \\
\text { abrasi } \\
\text { erosi pantai; } \\
\text { 3. Mengembangkan } \\
\text { keindahan kawasan } \\
\text { pandang pantai. }\end{array} \\
\end{array}$ & \\
\hline & $\begin{array}{l}\text { Rehabilitasi } \\
\text { Pemeliharaan joggingpath } \\
\text { track wisatawan }\end{array}$ & 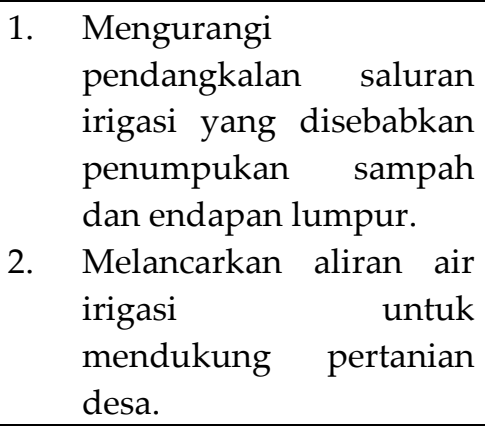 & \\
\hline & $\begin{array}{l}\text { Pembangunan/pengadaan } \\
\text { tandon air/bak penampung } \\
\text { air hujan atau air bersih dari } \\
\text { sumber mata air }\end{array}$ & $\begin{array}{l}\text { 1. } \begin{array}{l}\text { dan } \\
\text { mendekatkan akses } \\
\text { kubutuhan air bersih }\end{array} \\
\text { untuk penduduk desa; } \\
\text { 2. Membangun/pengadaan } \\
\text { baru untuk bak } \\
\text { penampung air hujan }\end{array}$ & \\
\hline & $\begin{array}{l}\text { Pemeliharaan saluran air } \\
\text { bersih dari sumber mata air } \\
\text { ke rumah-rumah penduduk }\end{array}$ & $\begin{array}{l}\text { 1. Mencegah kerusakan } \\
\text { saluran air bersih dari } \\
\text { sumber mata air ke } \\
\text { rumah tangga. } \\
\text { 2. Menjamin pemenuhan } \\
\text { kebutuhan air bersih } \\
\text { untuk penduduk }\end{array}$ & \\
\hline \multirow[t]{2}{*}{$\begin{array}{l}\text { Pembangunan, } \\
\text { pengembangan dan } \\
\text { pemeliharaan } \\
\text { sarana dan } \\
\text { prasarana } \\
\text { kesehatan } \\
\text { masyarakat }\end{array}$} & $\begin{array}{l}\text { Pembangunan penambahan } \\
\text { ruang rawat inap Poskesdes } \\
\text { (posyandu apung/perahu). }\end{array}$ & \begin{tabular}{lr} 
1. & \multicolumn{2}{l}{ Mengembangkan } \\
fasilitas & layanan \\
kesehatan & untuk \\
masyarakat & dan \\
wisatawan. & \\
2. & Menyiapkan unit untuk \\
penanganan darurat.
\end{tabular} & \\
\hline & $\begin{array}{l}\text { Pengadaan tambahan } \\
\text { peralatan kesehatan } \\
\text { emergency poskesdes }\end{array}$ & $\begin{array}{lr}\text { 1. } & \begin{array}{l}\text { Melengkapi } \\
\text { sarana }\end{array} \\
\text { kesehatan } & \text { prasarana } \\
\text { (medical }\end{array}$ & \\
\hline
\end{tabular}




\begin{tabular}{|c|c|c|}
\hline & & rescue) \\
\hline \multirow{4}{*}{$\begin{array}{l}\text { Pembangunan, } \\
\text { pengembangan dan } \\
\text { pemeliharaan } \\
\text { sarana } \\
\text { dan prasarana } \\
\text { pendidikan, sosial } \\
\text { dan kebudayaan }\end{array}$} & $\begin{array}{l}\text { Membangun amphitheater } \\
\text { di ruang publik pantai }\end{array}$ & $\begin{array}{l}\text { Menyediakan arena untuk } \\
\text { atraksi seni budaya di } \\
\text { kawasan pantai }\end{array}$ \\
\hline & $\begin{array}{l}\text { Penambahan bahanbahan } \\
\text { promosi dan buku edukasi } \\
\text { tentang pantai dan laut }\end{array}$ & $\begin{array}{l}\text { Mencukupi kebutuhan } \\
\text { informasi dan pengetahuan } \\
\text { wisatawan tentang terumbu } \\
\text { karang, penyu, ikan dan jenis } \\
\text { flora fauna laut lain nya } \\
\text { terkait paket wisata pantai } \\
\text { dan laut }\end{array}$ \\
\hline & $\begin{array}{l}\text { Membangun fasilitas } \\
\text { penunjang acara tradisi } \\
\text { "sedekah laut" }\end{array}$ & $\begin{array}{l}\text { Menyediakan ruang terbuka } \\
\text { yang aman dan nyaman bagi } \\
\text { kegiatan budaya lokal yang } \\
\text { memiliki nilai wisata }\end{array}$ \\
\hline & & $\begin{array}{l}\text { Mendorong interaksi sosial } \\
\text { dan budaya lokal tetap terjaga }\end{array}$ \\
\hline \multirow[t]{3}{*}{$\begin{array}{l}\text { Pengembangan } \\
\text { usaha ekonomi } \\
\text { masyarakat, } \\
\text { meliputi } \\
\text { pembangunan dan } \\
\text { pemeliharaan } \\
\text { sarana prasarana } \\
\text { produksi dan } \\
\text { distribusi }\end{array}$} & $\begin{array}{l}\text { Membangun pusat } \\
\text { budidaya, pembenihan dan } \\
\text { keramba ikan kerapu, } \\
\text { konservasi tukik penyu dan } \\
\text { karang/seareef }\end{array}$ & $\begin{array}{l}\text { 1. Mendorong kemampuan } \\
\text { nelayan budidaya untuk } \\
\text { mencukupi kebutuhan } \\
\text { benih dan produksi ikan, } \\
\text { 2. Tempat konservasi dan } \\
\text { fasilitas paket wisata } \\
\text { 3. Mendorong } \\
\text { meningkatnya } \\
\text { pendapatan } \\
\text { petani/nelayan dan } \\
\text { sekaligus PADes }\end{array}$ \\
\hline & $\begin{array}{l}\text { Rehabilitasi dan perluasan } \\
\text { tambatan perahu }\end{array}$ & 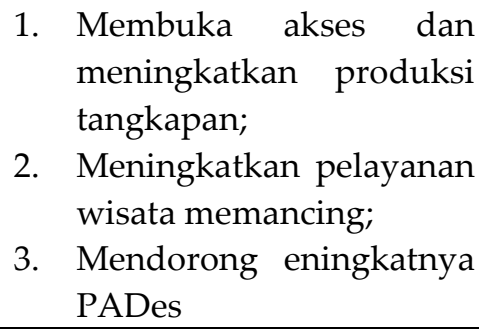 \\
\hline & Rehab pasar ikan & $\begin{array}{l}\text { 1. Meningkatkan pelayanan } \\
\text { transaksi hasil laut; } \\
\text { 2. Mengembangkan potensi } \\
\text { interaksi warga- } \\
\text { wisatawan untuk } \\
\text { membeli produksi laut } \\
\text { segar; } \\
\text { 3. Mendorong } \\
\text { meningkatnya PADes }\end{array}$ \\
\hline $\begin{array}{l}\text { Pembangunan dan } \\
\text { pengembangan }\end{array}$ & $\begin{array}{l}\text { Konservasi tukik penyu } \\
\text { dan terumbu karang/coral- }\end{array}$ & $\begin{array}{l}\text { 1. Melestarikan terumbu } \\
\text { karang; }\end{array}$ \\
\hline
\end{tabular}




\begin{tabular}{|c|c|c|}
\hline $\begin{array}{l}\text { sarana-prasarana } \\
\text { energi terbarukan } \\
\text { serta kegiatan } \\
\text { pelestarian } \\
\text { lingkungan hidup }\end{array}$ & seareef & $\begin{array}{l}\text { 2. Meningkatkan } \\
\text { kemanfaatan ekologis } \\
\text { aset desa. } \\
\text { 3. Paket wisata dan PADes }\end{array}$ \\
\hline & $\begin{array}{l}\text { Pengembangan Cemara } \\
\text { laut dan } \\
\text { pembibitan/penanaman } \\
\text { bakau }\end{array}$ & $\begin{array}{l}\text { Mengurangi risiko abrasi laut, } \\
\text { bencana intrusi air laut dan } \\
\text { penahan alami tsunami } \\
\text { Paket wisata dan } \\
\text { PADes }\end{array}$ \\
\hline & $\begin{array}{l}\text { Pengadaan sarana prasaran } \\
\text { pengelolaan sampah } \\
\text { terpadu bagi rumah tangga } \\
\text { dan kawasan wisata }\end{array}$ & 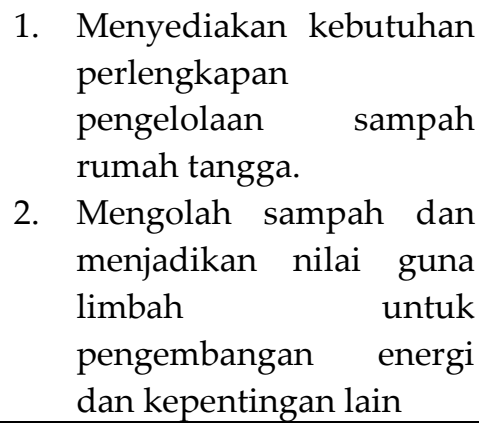 \\
\hline \multirow{3}{*}{$\begin{array}{l}\text { Peningkatan } \\
\text { investasi ekonomi } \\
\text { desa melalui } \\
\text { pengadaan, } \\
\text { pengembangan atau } \\
\text { bantuan alat-alat } \\
\text { produksi, } \\
\text { permodalan, dan } \\
\text { peningkatan } \\
\text { kapasitas melalui } \\
\text { pelatihan dan } \\
\text { pemagangan. }\end{array}$} & $\begin{array}{l}\text { Pelatihan benih kerapu, } \\
\text { tukik dan budidaya cemara } \\
\text { laut dan bakau }\end{array}$ & 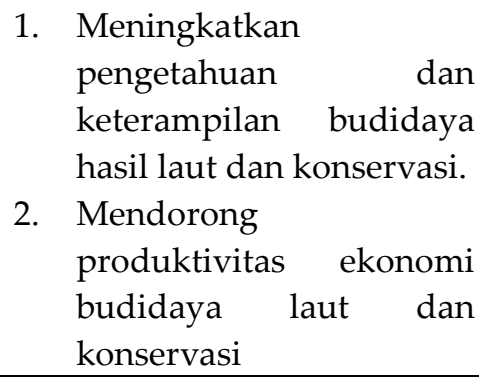 \\
\hline & $\begin{array}{l}\text { Kursus/pelatihan kerajinan } \\
\text { tangan (handycraft) } \\
\text { berbahan baku limbah laut } \\
\text { (kerang, kayu, bakau dan } \\
\text { cemara laut }\end{array}$ & $\begin{array}{ll}\text { 1. } & \begin{array}{l}\text { Meningkatkan nilai } \\
\text { ekonomi bahan baku } \\
\text { lokal. }\end{array} \\
\text { 2. } & \begin{array}{l}\text { Meningkatkan } \\
\text { keterampilan membuat } \\
\text { kerajinan } \\
\text { berbahan lokal }\end{array} \\
\end{array}$ \\
\hline & $\begin{array}{l}\text { Pelatihan kuliner dan } \\
\text { pengembangan makanan } \\
\text { lokal sebagai komoditas } \\
\text { strategi ekonomi-wisata }\end{array}$ & $\begin{array}{l}\text { Meningkatkan pengetahuan } \\
\text { dan kuliner, memproduksi } \\
\text { olahan hasil laut dan } \\
\text { sejenisnya sebagai penunjang } \\
\text { sektor wisata }\end{array}$ \\
\hline $\begin{array}{l}\text { Dukungan kegiatan } \\
\text { ekonomi baik yang } \\
\text { dikembangkan oleh }\end{array}$ & $\begin{array}{l}\text { Pelatihan kewirausahaan } \\
\text { desa untuk pemuda }\end{array}$ & $\begin{array}{l}\text { Mendorong tumbuhnya } \\
\text { minat kewirausahaan bagi } \\
\text { kalangan pemuda desa }\end{array}$ \\
\hline $\begin{array}{lr}\text { BUM } & \text { Desa-BUM } \\
\text { Antar } & \text { Desa, } \\
\text { maupun } & \text { oleh } \\
\text { kelompok dan } & \end{array}$ & $\begin{array}{l}\text { Pengembangan bisnis dan } \\
\text { pemetaan kelayakan } \\
\text { BUMDesa dan BUM Antar } \\
\text { Desa }\end{array}$ & $\begin{array}{l}\text { Perangkat desa dan } \\
\text { masyarakat mengetahui } \\
\text { posisi strategis unit bisnis } \\
\text { yang akan dikembangkan }\end{array}$ \\
\hline
\end{tabular}




\begin{tabular}{|c|c|c|}
\hline $\begin{array}{l}\text { lembaga ekonomi } \\
\text { masyarakat Desa } \\
\text { lainnya. }\end{array}$ & & $\begin{array}{l}\text { melalui } \text { BUMDes dan } \\
\text { menjajaki peluang strategis } \\
\text { BUM Antar Desa }\end{array}$ \\
\hline $\begin{array}{l}\text { Bantuan } \\
\text { peningkatan } \\
\text { kapasitas untuk } \\
\text { program } \quad \text { dan } \\
\text { kegiatan ketahanan } \\
\text { pangan Desa }\end{array}$ & $\begin{array}{l}\text { Musyawarah/rembug warga } \\
\text { untuk menfungsikan } \\
\text { kembali tradisi lumbung } \\
\text { padi/hasil pertanian lainnya }\end{array}$ & $\begin{array}{l}\text { Merevitalisasi } \\
\text { lumbung padi desa }\end{array}$ \\
\hline $\begin{array}{l}\text { Pengorganisasian } \\
\text { masyarakat, } \\
\text { fasilitasi, bantuan } \\
\text { hukum masyarakat } \\
\text { dan pelatihan } \\
\text { paralegal di Desa }\end{array}$ & Pelatihan paralegal desa & $\begin{array}{l}\text { Melatih keterampilan } \\
\text { warga memetakan masalah } \\
\text { dan penyelesaiannya di luar } \\
\text { peradilan }\end{array}$ \\
\hline & $\begin{array}{l}\text { Pelatihan penyelesaian } \\
\text { mediasi sengketa aset di } \\
\text { desa untuk warga desa }\end{array}$ & $\begin{array}{l}\text { Melatih keterampilan bagi } \\
\text { warga tentang penyelesaian } \\
\text { sengketa aset di desa }\end{array}$ \\
\hline $\begin{array}{lr}\text { Promosi } & \text { dan } \\
\text { edukasi } & \text { kesehatan } \\
\text { masyarakat } & \text { serta } \\
\text { gerakan } & \text { hidup } \\
\text { bersih dan sehat }\end{array}$ & $\begin{array}{l}\text { Festival makanan laut } \\
\text { higienis "Pesisir Laut }\end{array}$ & $\begin{array}{l}\text { 1. Mengangkat keunggulan } \\
\text { ekonomi menu laut; } \\
\text { 2. Sebagai ruang promosi } \\
\text { produk olahan makanan } \\
\text { berbasis potensi lokal; } \\
\text { 3. Mendorong gaya hidup } \\
\text { sehat ala pesisir }\end{array}$ \\
\hline & $\begin{array}{l}\text { Lomba melukis/menulis } \\
\text { keindahan alam dan hidup } \\
\text { bersi dan sehat "anak } \\
\text { pantai" }\end{array}$ & $\begin{array}{l}\text { 1. Mengenalkan pola hidup } \\
\text { bersih sejak dini kepada } \\
\text { anak dan orang tua. } \\
\text { 2. Mencari bakat anak-anak } \\
\text { pantai. } \\
\text { 3. Paket wisata }\end{array}$ \\
\hline \multirow{2}{*}{$\begin{array}{l}\text { Dukungan terhadap } \\
\text { kegiatan } \\
\text { pengelolaan Pantai } \\
\text { untuk kepentingan } \\
\text { Desa }\end{array}$} & $\begin{array}{l}\text { Pelatihan pengolahan hasil } \\
\text { laut dan pantai untuk petani } \\
\text { budidaya dan nelayan } \\
\text { tangkap }\end{array}$ & $\begin{array}{l}\text { Membekali keterampilan } \\
\text { pengolahan sumber daya laut } \\
\text { dan pantai untuk para petani } \\
\text { dan nelayan }\end{array}$ \\
\hline & $\begin{array}{l}\text { Membentuk/merevitalisasi } \\
\text { kelembagaan lokal untuk } \\
\text { menjaga kelestarian pantai } \\
\text { dan laut termasuk bakau, } \\
\text { terumbu karang dan zonasi } \\
\text { tangkap dan konservasi }\end{array}$ & \begin{tabular}{lr} 
Mendorong & \multicolumn{2}{c}{ berfungsinya } \\
kembali kelembagaan lokal \\
desa yang memiliki peran \\
terhadap produksi dan \\
konservasi laut pantai.
\end{tabular} \\
\hline
\end{tabular}

Sumber: Data Lapangan Diolah Penulis, 2020 
Jurnal Administrasi Negara

ISSN : 2598-4039 (Online)

ISSN : 2302-2231 (Print)
Muhammad Lukman Hakim

Prodi Ilmu Pemerintahan FISIP Universitas Brawijaya Malang

\section{SIMPULAN}

Kabupaten Blitar memiliki wilayah kepesisiran yang terbentang dalam 14 Desa meliputi: Kecamatan Bakung: (1)Tumpakepuh, (2)Plandirejo,

(3)Tumpakoyot,

(4)Sidomulyo,

(5)Bululawang, Kecamatan Wonotirto:

(6)Gununggede,

(7)Kaligrenjeng,

(8)Ngadipuro,

(9)Tambakrejo,

Kecamatan Penggungrejo: (10)Serang, (11)Sumbersih, Kecamatan Wates: (12)Tugurejo,

(13)Tulungrejo,

(14)Ringinrejo. Keempat belas desa tersebut memiliki tingkat perkembangan yang berbeda, sehingga dapat diidentifikasi dengan tipologi desa yang berbeda pula. Berdasarkan hasil analisis SWOT dan penentuan kuadran strategi dapat diklasifikasikan bahwa desa-desa pesisir di Kabuapaten Blitar tergolong sebagai desa tertinggal dan berkembang. Hasil klasifikasi tersebut maka strategi yang dapat dipilih adalah strategi agresif bertumbuh. Desa yang saat ini telah berkembang pesat adalah Tambakrejo, sementara desa-desa yang lain tingkat perkembangannya belum secepat Desa Tambakrejo. Setiap desa pesisir di wilayah Kabupaten Blitar harus didorong dan difasilitasi untuk berubah dalam klasifikasi desanya, seperti tipologi desa berkembang dapat berubah menjadi desa maju dan desa tertinggal menjadi desa berkembang.

Untuk dapat mengembangkan desa desa pesisir tersebut maka diperlukan upaya dalam sejumlah langkah:
1) Saat ini telah dibangun dan dikembangkan infrastruktur untuk mendukung sarana dan prasarana di desa pesisir Blitar, khususnya wilayah Desa Tambakrejo. Pembangunan insfrastruktur belum merata disebabkan oleh perbedaan kondisi geografis wilayah, sehingga memerlukan kajian dan analisis kewilayahan yang lebih mendalam.

2) Pembangunan di wilayah desa pesisir Kabupaten Blitar tidak terlepas dari anggaran dana desa (ADD), sehingga pemanfaatan ADD dalam pengembangan dan pembangunan desa pesisir di Kabupaten Blitar harus disesuaikan pula dengan pedoman pemanfaatan ADD yang diatur oleh Kemendagri.

3) Pengelolaan dan pengembangan desa pesisir di Kabupaten Blitar merupakan upaya bersama yang bersifat holistik-komprehansif dengan melibatkan berbagai stakeholder seperti: (pihak pemerintah) Pemerintah Kabupaten Blitar, Kecamatan, Desa, Bappeda, Perhutani, Dinas Perikanan, KKP, institusi lain yang terkait, (pihak swasta) penanam modal dan pengembangan desa/wilayah pesisir di Blitar, dan masyarakat lokal.

4) Realisasi dan operasional zonasi kawasan pesisir Kabupaten Blitar memerlukan upaya cepat dan terarah untuk mendukung strategi agresif bertumbuh.

Melalui sejumlah langkah di atas diharapkan upaya Bersama untuk 
Jurnal Administrasi Negara

ISSN : 2598-4039 (Online)

ISSN : 2302-2231 (Print)
Muhammad Lukman Hakim

Prodi Ilmu Pemerintahan FISIP

Universitas Brawijaya Malang meningkatkan taraf hidup masyarakat melalui peningkatan indeks desa dapat dilakukan, sehingga kedepan sejumlah desa yang menjadi lokasi penelitian dapat didorong menjadi desa mandiri.

\section{REFERENSI}

Agusta, Ivanovich dan Fujiartanto (Ed). 2014. Indeks Kemandirian Desa. Jakarta: IPB dan YOI.

Ananda, Faisar dan Watni Marpaung. 2016 Metodologi Penelitian Hukum Islam. Jakarta: Prenadamedia Group

Badiklat Provinsi Jawa Timur dan CSWS FISIP Unair. 2014. Tugas dan Fungsi Kepala Desa berdasarkan UU No. 6 tahun 2014, Handout Sosialisasi dan Bimtek Pengembangan Kapasitas Camat dan Kepala Desa untuk Menunjang Tata Kelola Desa Mandiri, Sejahtera, dan Partisipatoris (Sesi 6). Surabaya: Badan Diklat Prov. Jawa Timur-CSWS FISIP Unair.

Daoed Joesoef, Membangun Desa. Kompas, 26 Maret 2015, hlm 6

Departemen Dalam Negeri. 2007. Naskah Akademik RUU Desa, Jakarta, hlm. 9-11

HB Sutopo. 2006, Metode Penelitian Kualitatif: Teori Dan Aplikasinya Dalam Penelitian. Surakarta: UNS Press

Irawan, Nata. 2017. Tata Kelola Pemerintahan Desa Era UU Desa. Jakarta: Yayasan Pustaka Obor
Irwanto. 2006. Focus Group Discussion (FGD): Sebuah Pengantar Praktis. Jakarta: Yayasan Pustaka Obor Indonesia

LAN dan BPKP. 2000. Akuntabilitas dan Good Governance. Jakarta: LAN dan BPKP. Hlm. 5

Moleong, Lexy J. 1999. Metodologi Penelitian. Bandung : Remaja Rosdakarya.

PKDOD. 2015. Policy Brief Implementasi UU Desa dan Tantangan Pengembangan Kapasitas Pemerintah Desa. Jakarta: PKDOD.

Pramusinto, Agus dan M. Syahbudin Latief. 2011. Dinamika Good Governance di Tingkat Desa. Jurnal Ilmu Administrasi Negara, Volume 11, Nomer 1, hlm 1-13

Pratikno. 2007. Governance dan Krisis Teori Organisasi. Dalam Jurnal Kebijakan dan Administrasi Publik Volume 11, Nomer 2, hlm.121 - 138

Salim, Agus, et.all. 2017. Research Report: Indonesia's Village law, Enabler or Constraint for more accountable government. Jakarta: Pattiro dan Institute of Development Studies.

Sitepu, Yovita Sabarina. 2011. Paradigma dalam Teori Organisasi dan Implikasinya pada komunikasi Organisasi. Dalam Jurnal AlAzhar Indonesia Seri Pranata Sosial, Vol.1, No. 2. hlm 83-91 
Jurnal Administrasi Negara

ISSN : 2598-4039 (Online)

ISSN : 2302-2231 (Print)
Muhammad Lukman Hakim

Prodi Ilmu Pemerintahan FISIP Universitas Brawijaya Malang
Solekhan, Moch. 2014. Penyelenggaraan Pemerintahan Desa Berbasis Partisipasi Masyarakat. Malang: Setara Press.

Sugiyono. 2011. Metode Penelitian Kuantitatif, Kualitatif, dan RED. Bandung: Penerbit Alfabeta.

Utomo, Sad Dian (Ed). 2016. Praktik baik Desa dalam Implementasi UU desa. Jakarta: Pattiro.

Undang-Undang No.6 tahun 2014 tentang Desa. Jakarta: Sekretariat Negara
Wardiyanto, Bintoro. 2014. Otonomi dan Rekognisi Desa: Perubahan ke arah Good Village Governance (GVG), dalam Percikan Pemikiran tata Kelola dan Pembangunan Desa. Surabaya: Airlangga University Press.

Zed, Mestika. 2008 Metode Penelitian Kepustakaan. Jakarta: Yayasan Obor Indonesia 